J. Clin. Chem. Clin. Biochem.

Vol. 20, 1982, pp. 603-613

\title{
Somatostatin - A Regulatory Peptide of Clinical Importance
}

By $N$. Bethge

Institut für Pathologie, Universitätsklinikum Steglitz, Freie Universität Berlin, West Germany,

F. Diel and K. H. Usadel

Zentrum der Inneren Medizin der Universität Frankfurt/M, West Germany

(Received December 23, 1981/May 17, 1982)

In memoriam Professor Dr. E. Altenähr

Summary: Somatostatin was first discovered in the hypothalmus and has since been located in many parts of the central and peripheral nervous system, as well as in the pancreas and the gastrointestinal tract. Its main biological activity is to inhibit the action of somatotropin (growth hormone, STH, GH) and a number of other hormones. The therapeutic value of somatostatin has been demonstrated in the treatment of both acute bleeding gastric ulcers and acute pancreatitis. In addition, the measurement of somatostatin in the blood is a useful method for the screening of somatostatin-producing tumours. This paper reviews the location, action, clinical significance and measurement of somatostatin.

\section{Somatostatin - Ein Regulatorpeptid mit klinischer Bedeutung}

Zusammenfassung: Somatostatin, zuerst im Hypothalamus entdeckt, ist in vielen Teilen des zentralen und peripheren Nervensystems, im Pankreas und im Gästrointestinaltrakt lokalisiert. Seine biologische Hauptwirkung ist die Hemmung von Somatotropin (GH, STH) und einer Vielzahl anderer Hormone. Der therapeutische Wert von Somatostatin konnte bei der Behandlung von akuten Magenulkusblutungen und akuter Pankreatitis gezeigt werden. Die Somatostatin-Bestimmung im Blut stellt eine wertvolle Methode bei der Suche nach einem somatostatinproduzierenden Tumor dar. Die Lokalisation, Wirkung, klinische Bedeutung und Bestimmung von Somatostatin wird dargestellt.

\section{Introduction}

Intensive research has been carried out to identify the hormones of the hypothalamus which influence pituitary function. So far, three hypothalamic hormones have been identified and their biological effects in animals and man investigated: thyroliberin (thyrotropin-releasing hormone, TRH), identified in 1969 by Guillemin (1) and Schally (2); Luliberin (luteiniżing-hormone-releasing hormone, LHRH), isolated in 1971 by Schally (3); and somatostatin, rẹported by Guillemin in 1973 (4) and by Schally in $1976(5)$. Figure 1 shows the chemical struc= tures of these three hormones.

The tuberohypophyseal neurons are believed to synthesize, transport, and release the hypothalamic hormones into perivascular spaces in the median eminence of the hypothalamus. The capillaries of the capillary plexus in this region are fenestrated and therefore permeable to relatively large molecules. The long portal veins of the hypothalamic-hypophyseal portal system drain the capillary plexus into the sinusoids of the adenohypophysis. By this pathway, the hypothalamic hormones control adenohypophysis hormone secretion (fig. 2). Certain of these hormones affect more than one pituitary hormone: e.g., thyroliberin causes the release of thyrotropin (thyrotropic hormone, TSH) $(1,2)$ and prolactin $(6)$; luliberin releases lutropin (luteinizing hormone, $\mathrm{LH}$ ) and follitropin (folliclestimulating hormone, FSH) $(3,7)$, and somatostatin inhibits the secretion of somatotropin (4) and thyrotropin (8). 


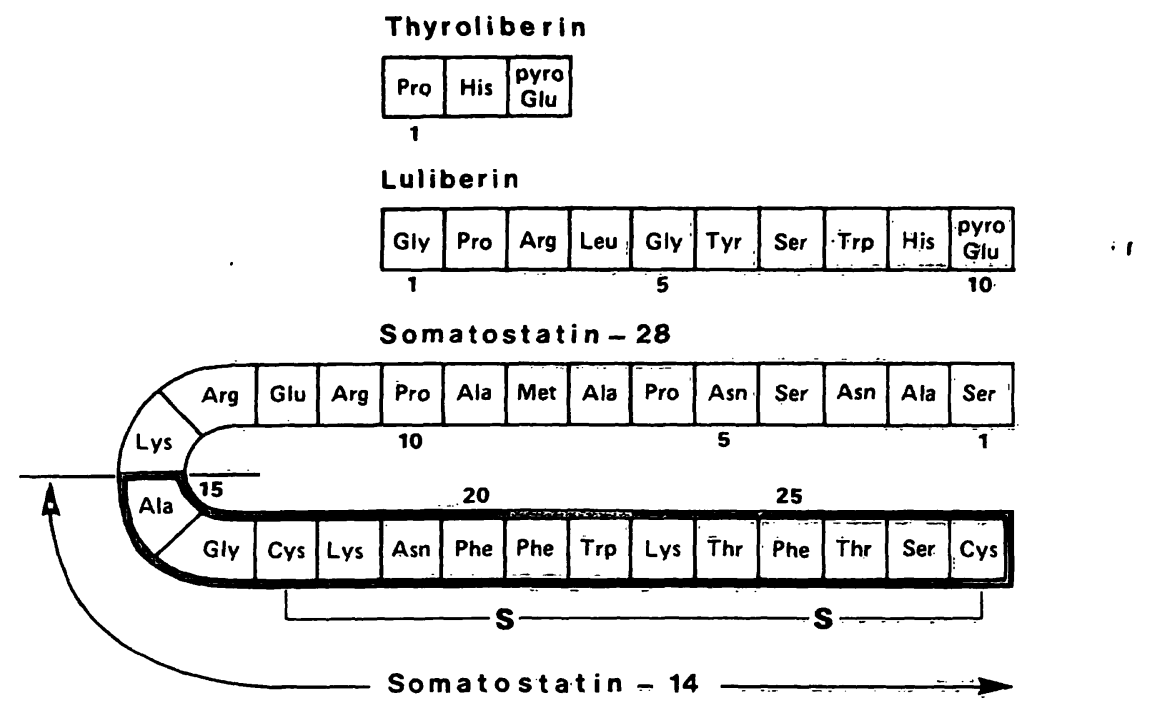

Fig. 1. Amino acid sequences of hypothalamic hormones which influence pituitary functions.

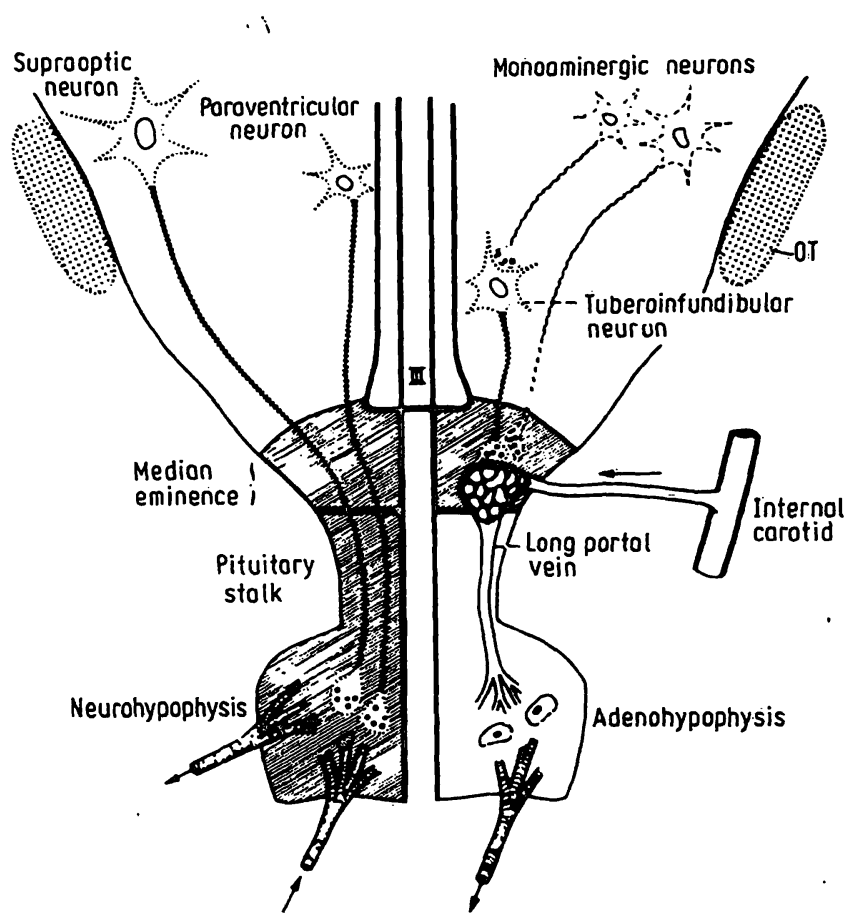

Fig. 2. Diagram of the hypothalamic-pituitary axis in coronal section.

Left: The hypothalamic-neurohypophyseal system. Supraoptic and paraventricular axons terminate on blood vessels in the posterior pituitary (neurohypophysis).

Right: The hypothalamic-adenohypophyseal system. Tuberoinfundibular neurons, believed to be the source of the hypothalamic regulatory hormones, terminate on the capillary plexus in the median eminence. The pituitary portal system is derived from branches of the internal carotid, which forms a primary capillary bed in the median eminence. The long portal veins drain the capillary plexus into the sinusoids of the anterior pituitary (adenohypophysis). Supraoptic, paraventricular, and tuberoinfundibular neurons are all classed as neurosecretory cells. The activity of tuberoinfundibular neurons is influenced by monoaminergic cells. OT = optic tract. (From Martin, J. B. (1977) Clinical Neuroendocrinology, F. A. Davis Company, Philadelphia, p. 13, with permission).

\section{Localizàtion of Somatostatin}

Tissue localization of somatostatin has been elucidated mainly by immunohistochemistry and by radioimmuno: assay. For this reason, the term "somatostatin-like immunoreactivity" may be more appropriate in this context than "somatostatin".

Tab. 1. Localization of Somatostatin.

\begin{tabular}{lll}
\hline Localization & Authors & $\begin{array}{l}\text { Ref- } \\
\text { er- } \\
\text { ence }\end{array}$ \\
\hline
\end{tabular}

\section{Central nervous} system

1.1 Hypothalämus

*Burgus et al. (1973) $\quad 166$

* Brazeau et al. (1973)

* Schally et al. (1976)

Hökfelt et al (1974)

Alpert et al. (1976) 168

Dube et al. (1975) 169

King et al. (19.75) $\quad 170$

Pelletier et al. (1975) 171

Setalo et al. (1975) 172

Brownstein et al. (1975) 173

1.2 Extrahypothalamic regions

1.2.1 Pituitary infundibular Patel et al. (1977) process (neurohypophysis)

1.2.2 Pineal gland

1.2.3 Cerebral cortex

\subsubsection{Retina}

1.2.5 Cerebellum

1.2.6 Spinal cord

2. Peripheral nervous

Patel \& Reichlin (1978) . 175

Pevet et al. (1980) $\quad 176$

Luft et al. (1978) 26

Shapiro et al. (1979) $\quad 177$

Krisch \& Leonhart (1979) 178

Yamada et al. (1980) 17.9

Patel \& Reichlin (1978) 175

Hökfelt et al. (1976)' 180

Forssmann (1978) 181

Burnweit \& Forssmann (1979) 182 - system

2.1 Spinạl ganglion

Hộkfelt et al. (1976) 180 
Tab. 1. Continued.

\begin{tabular}{|c|c|c|c|}
\hline \multicolumn{2}{|c|}{ Localization } & \multirow{2}{*}{$\begin{array}{l}\text { Authors } \\
\text { Hökfelt et al. (1977) } \\
\text { Costa et al. (1977) } \\
\text { Elde et al. (1978) }\end{array}$} & \multirow{2}{*}{$\begin{array}{l}\text { Ref- } \\
\text { er- } \\
\text { ence }\end{array}$} \\
\hline 2.2 & $\begin{array}{l}\text { Myenteric } \\
\text { (Auerbach's) plexus }\end{array}$ & & \\
\hline 3. & Pancreas & $\begin{array}{l}\text { Luft et al. (1974) } \\
\text { Dubois et al. (1975) } \\
\text { Hökfelt et al. (1975) } \\
\text { Orcl et al. (1975) } \\
\text { Polak et al. (1975) } \\
\text { Rufener et al. (1975) } \\
\text { Parsons et al. (1976) } \\
\text { Forssmann et al. (1978) } \\
\text { Spiess et al. (1979) } \\
\text { Noe et al. (1979) } \\
\text { Oyama et al. (1980) } \\
\text { Bethge (1982) }\end{array}$ & $\begin{array}{r}9 \\
186 \\
10 \\
187 \\
11 \\
12 \\
188 \\
189 \\
190 \\
191 \\
192 \\
164\end{array}$ \\
\hline 4. & $\begin{array}{l}\text { Gastro-intestinal } \\
\text { tract }\end{array}$ & & \\
\hline 4.1 & Stomach & $\begin{array}{l}\text { Hökfelt et al. (1975) } \\
\text { Poläk et al. (1975) } \\
\text { Rufener et al. (1975) } \\
\text { Arimura et al. (1975) }\end{array}$ & $\begin{array}{l}10 \\
11 \\
12 \\
13\end{array}$ \\
\hline 4.2 & $\begin{array}{l}\text { Duodenum, jejunum, } \\
\text { and ileum }\end{array}$ & $\begin{array}{l}\text { Polak et al. (1975) } \\
\text { Pradayrol et al. (1978) } \\
\text { *Pradayrol et al. (1980) }\end{array}$ & 11 \\
\hline 4.3 & Colon & Lehy et al. (1981) & 16 \\
\hline
\end{tabular}

5. Other tissues and body fluids

5.1 Thyroid

5.1.1 Medullary carcinoma of the thyroid

5.2 Thymus

5.3 Chorionic villi; decidua of early pregnancy

5.4 Plașma

5.5 Cerebrospinal fluid

5.6 Urine

5.7 Amniotic fluid

6. Somatostatinoma (human)

6.1 of the pancreas

6.2 of the duodenum

6.3 of the jejunum

\footnotetext{
* Defined by isolation and amino acid composition; all other data are evaluated by immunological techniques.
}

Noorden et al. (1977) Buffa et al. (1979)

Sundler et al. (1977)

Capella et al. (1978)

Berelowitz et al. (1980)

Sundler et al. (1978)

Kumasäka et al. (1979)

Pimstone et al. (1977)

Harris et al. (1978)

Bethge et al. (1981)

Mackes et al. (1981)

Patel et al. (1977)

Diel et al. (1977)

Kronheim et al. (1977.)

Fitz-Patrick \& Patel (1979)

Ganda et al. (1977)

Kovacs et al. (1977)

Galmiche et al. (1978)

de Nutte et al. (1978)

Krejs et al. (1979)

Galmiche et al. (1980)

Lowry et al. (1981)

Axelrod et al. (1981)

Kaneko et al. (1979)

Alumets et al. (1978)
Somatostatin, which was first discovered in the hypothalamus is now known to be widely distributed throughout the brain (tab. 1; fig. 3).

Larsson et al. (1977)

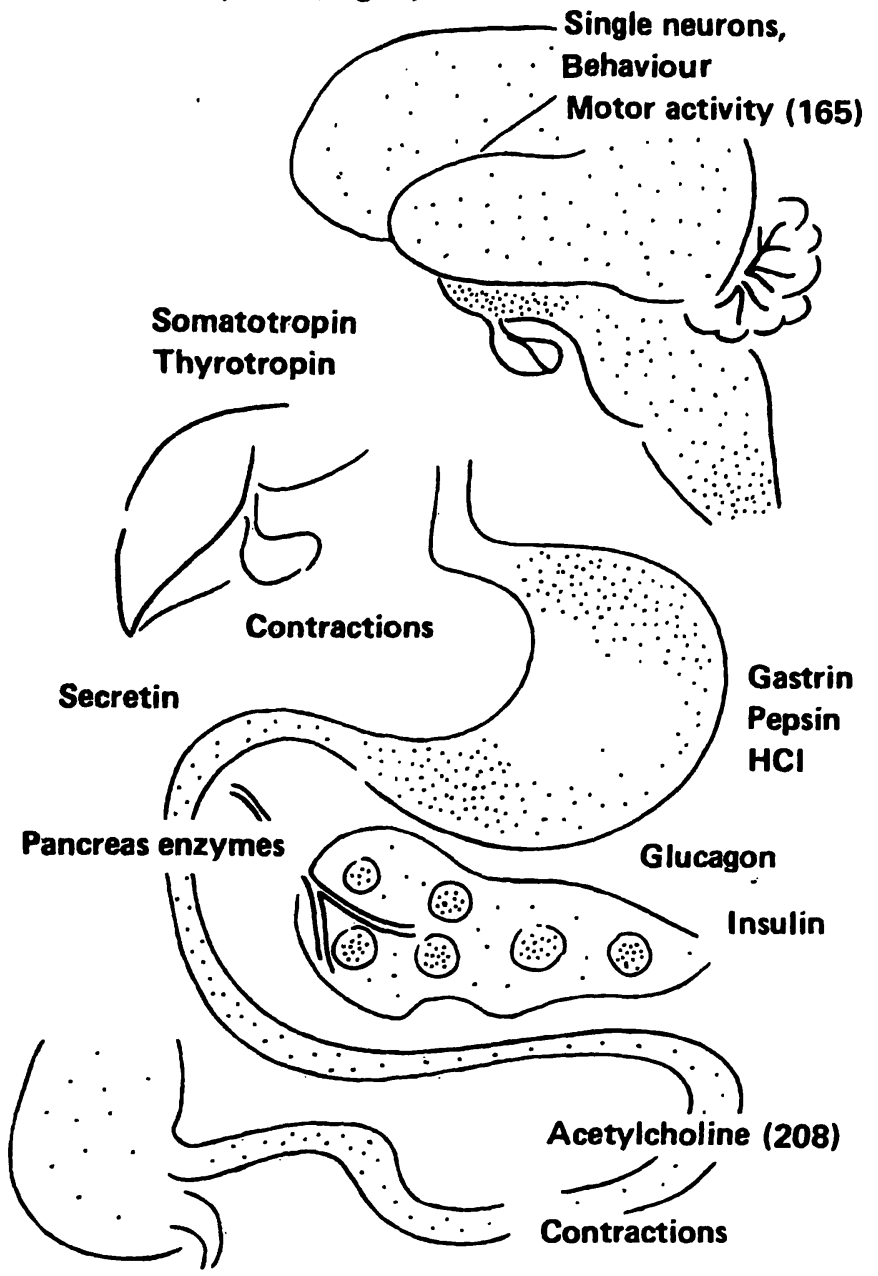

Fig. 3. Multiple locations of somatostatin and multiple effects of somatostatin. (From Guillemin, R. (1978) Science 202, p. $397,(C)$ The Nobel Foundation 1978, with permission).

The hormone has also been detected in pancreatic islet cells (Luft et al. 1974) (9) and in the so-called D-cells of the stomach and gut (10-16). Thyroliberin is another peptide which is normally associated with the brain, but which has also been found in the pancreas and in the gastrointestinal tract (17). Conversely, many gastrointestinal peptides such as substance $P(18,19)$, vasoactive intestinal peptide (VIP) $(20,21)$, neurotensin (22), gastrin (23) and insulin 24) have been isolated from brain tissue.

However, somatostatin is not restricted to brain and gut. blood, cerebrospinal fluid, amniotic fluid, retina and tumours of the pancreas and gut (see tab. 1 ; fig. 3 ). Intracellularly, somatostatin has been identified in the Golgi complex $(25,26)$.

The disseminative distribution of somatostatin suggests a mainly paracrine function for the peptide, i.e. somatostatin acts on neighbouring cells and tissues rather than on some distant target receptors through dissemination of its signal by the bloodstream (27). 


\section{Biosynthesis of Somatostatin}

After the discovery of the existence of prohormones as biosynthetic precursors (e.g.: insulin, glucagon, gastrin, cholecystokinin, parathyrin, $\beta$-melanotropin and $\beta$-endorphin) (see l.c. (28) for review), the acceptance of the formation of a series of peptide hormones from a single precursor by post-translational cleavage has by now become commonplace (29-32). In view of this and the fact that many reports of the occurrence of somatostatin are based on immunological evidence, it is hardly surprising that there is some conflict as to the exact nature of the peptide, but that there is some consensus on its biosynthesis in the pancreas and hypothalamus. The primary structure of a big-somatostatin was first described in 1980 by Pradayrol et al. (15). The big-somatostatin from porcine intestine is an octacosapeptide, the so-called "somatostatin-28", and its region 15-28 represents the previously known tetradecapeptide somatostatin (somatostatin-14). Bigsomatostatins from both pig and sheep hypothalamus were found to have identical structures $(33,34)$.

Another big-somatostatin, a pentacosapeptide (somatostatin-25) was found by Böhlen et al. 1980 (33). This may be a further intermediate of the pathway to the matured somatostatin-14. The $\mathrm{N}$-terminal extension in big-somatostatin is linked to the tetradecapeptide through an Arg-Lys peptide bond, which is the characteristic bond susceptible to cleavage by trypsin-like enzymes. Both somatostatin-28 and somatostatin-14 are released from the median eminence synaptosomes (35), and it has been shown that subcellular fractions of the hypothalamus can convert somatostatin-28 to somatostatin-14 (36).

Recent evidence from three independent groups has demonstrated the existence of mRNA coding for a precursor of somatostatin in angler fish pancreas (3740). Moreover, the complete amino acid sequence of this preprosomatostatin has been deduced from sequence analyses of cloned $\operatorname{cDNA}(37,39)$. This precursor contains a signal peptide which may be released during the transit into the endoplasmic reticulum. The resultant pancreatic prosomatostatin would be approximately 97 amino acid residues with $M_{\mathrm{r}}=10600$ and has the somatostatin-28 at the COOH-terminus (37).

In hypothalamic extracts, a $15000 M_{\mathrm{r}}$ precursor of the tetradecapeptide somatostatin has been characterized $(41,42)$. In addition, a hypothalamic extract containing protease(s) capable of selectively converting this $M_{\mathrm{r}}$ 15000 precursor into somatostatin-14 has also been described (43).

In conclusion, to date, there is no clear evidence that somatostatin-14 is formed from somatostatin-28 and not from another intermediate within the event of posttranslational modification.

\section{Catabolism of Somatostatin}

Specific proteolytic enzymes have been described for the degradation of other regulatory peptides such as luliberin and thyroliberin (44-46). In the brain, somatostatin may be cleaved by an indigenous neutral endopeptidase (cathepsin M) with specificity for Trp-8/Lys-9 (47). Experiments on somatostatin analogues have shown that the amino acid sequence from $7-10$ is important for biological activity (48). It is therefore possible that the cleavange of somatostatin by cathepsin- $M$ is of real catabolic significance. Intravenous injection of somatostatin is followed by a rapid disappearance of the peptide from the blood. The half-life of somatostatin in man has been calculated to be $1.7 \mathrm{~min}$ by radioimmunoassay and $1.9 \mathrm{~min}$ by radioreceptorassay $(49,50)$ as compared to the $1.1 \mathrm{~min}$ and $3.3 \mathrm{~min}$, respectively, reported by Sheppard et al. (51). In the rat, the half life of somatostatin- 28 is significantly longer than that of somatostatin -14 (52). The mechanisms involved in this rapid disappearance from the bloodstream are not clear. The most likely sites for elimination and excretion of hypothalamic hormones are:

- elimination by circulating peptidaseses,

- distribution and binding to receptor sites in various tissue beds,

- elimination by the liver and kidneys.

It has been shown by McMartin \& Purdon (53) that a plasma aminopeptidase can convert somatostatin to a biologically active peptide (des-Ala-1)-somatostatin. In a recent report, the dissappearance of tritiated somatostatin from the blood of rats after intravenous injection was demonstrated by the uptake of $70 \%$ of the label in the large peripheral tissues such as muscle, skin and intestine (54). In the same report, it was stated that less than $10 \%$ of the injected label was recovered from the liver and kidneys of the rats. More experiments will be required before the true role of enzymic degradation in the removal of somatostatin from the blood can be elucidated.

\section{Action of Somatostatin}

\section{Somatostatin -28 and somatostatin-14}

Before the numerous effects of somatostatin are described, two questions have to be raised:

(a) what is the biologically active form of somatostatin, and

(b) what is known about the receptor sites of somatostatin in the tissue and its intracellular effects?

If somatostatin-28 is an intermediate of the mature somatostatin-14, the big-somatostatin should have less biological activity than somatostatin-14. Somatostatin $=28$, however, shows equipotency with somatostatin-14 in the inhibition of somatotropin and prolactin on a molar 
basis in vitro (55). On a molar basis, somatostatin- 28 has been found to be twice as active as somatostatin-14 in inhibiting plasma glucagon and 10 times more active in inhibiting plasma insulin in the pancreas (55).

Other comparative studies support these results and also report somatostatin- 28 to be a more potent inhibitor of somatotropin in man $(56,57)$.

These differences in the inhibitory power of the two peptides suggest that somatostatin-28 is not only a presumable intermediate of somatostatin-14. A factor contributing in part to the more potent biological activity of somatostatin- 28 could be the longer half life of the larger peptide (52).

\section{Mode of action}

Investigations on the somatostatin receptors in rat pituitary tumour cell membrane were first performed by Schonbrunn and Tashjian Jr. (58). They described receptor sites for somatostatin and found that only those cell strains which had somatostatin receptors could respond to the hormone. In addition, the number of somatostatin receptors was modulated by thyroliberin (59). From other hormones, for example, insulin, it is known that the number of receptor sites in a cell is regulated by the hormone itself (60). Binding of somatostatin to pituitary plasma membrane has also been reported (61). Recently, Srikant \& Patel demonstrated that there are different receptors for somatostatin-28 and somatostatin-14 in the normal rat pituitary and cerebral cortex $(62,63)$. In comparison to somatostatin-14, somatostatin-28 shows a higher affinity for pituitary receptors than for cerebral cortex receptors.

A specific somatostatin binding factor in the cytosol of the dark islets cell area of the chicken pancreas has been demonstrated $(64,65)$. Another group (66) found a somatostatin binding protein while investigating a number of tissues (mainly from the rat). In both species, specificity of binding was demonstrated. However, differences in the data reported suggest differences in the nature of the somatostatin binding. Secretion vesicles isolated from pancreas islet cells have also been shown to exhibit somatostatin binding (67).

It therefore appears that there are specific binding sites in the somatostatin target tissue, but its exact nature and role in the initiation of the biological response are still unclear. Inhibition generated by somatostatin is accompanied by an intracellular decrease in cyclic AMP levels $(68,69)$ and an increase of cyclic GMP, respectively (70). Moreover, somatostatin specifically inhibits the cyclic AMP-dependent protein kinase activity of secretion vesicles isolated from pancreatic islets and the anterior pituitary (71).

\section{Pituitary hormones}

Somatostatin inhibits the secretion of somatotropin in animals and in man after virtually all known physiologi- cal and pharmacological stimuli, e.g., arginine (72), $L$-dopa (72), insulin-induced hypoglycaemia $(73,74)$, sleep in normal subjects (75) and in patients with somatotropin-producing pituitary tumours as in acromegaly $(74,76)$. Stimulation of thyrotropin by thyroliberin can be abolished by somatostatin (8). There is no effect on the thyroliberin-induced prolactin secretion in vivo, but an inhibition of prolactin secretion in vitro has been achieved (77). Under pathological conditions, somatostatin lowers prolactin levels in patients with acromegaly, but not in normal subjects (78).

However, these results were not supported by other authors (74). In man, normal corticotropin levels are not influenced by somatostatin $(74,79)$, but the elevated corticotropin levels in patients with Cushing's disease or Nelson's disease are lowered by somatostatin infusion (80-82). Lutropin and follitropin show no response to somatostatin (79).

\section{Endocrine pancreas}

In 1973, Alberti et al. (83) reported that plasma insulin levels were decreased after somatostatin infusion. The same effect on glucagon has also been described $(84,85)$. In normal man, infusion of somatostatin lowers plasma glucose levels. This fact indicates the important physiological role of glucagon in glucose homeostasis (86). The pancreatic polypeptide produced by the F-cells (87) in the pancreatic islets is also suppressed by somatostatin (88). Figure 4 summarizes the influence of somatostatin on glucose homeostatis.

\section{Exocrine pancreas and gastrointestinal tract}

Somatostatin has a strong effect on various gastrointestinal hormones and the function of the digestive system. For example, somatostatin inhibits the release of gastrin $(89,90)$, pepsin secretion (91), cholecystokinin-pancreozymin (92), secretin (93), motilin (94) and VIP (vasoactive intestinal peptide) in VIP-producing tumours (95). Conversely, experiments on isolated perfused pancreas have shown that somatostatin release is stimulated by gastrointestinal peptides like GIP (gastric inhibitory peptide), VIP, glucagon, glucose and arginine (96-99).

Somatostatin may also reduce duodenal motility (100), gall bladder contractions (92) and gastric emptying (93). Splanchnic blood flow is surprisingly reduced during continuous intravenous somatostatin infusion in man and animals (101-104).

\section{Adrenal gland}

It has been reported that somatostatin inhibits reninantiotensin-aldosterone adrenal cortex stimulation in vivo (105-107). Since glomerulosa cells from the adrenal cortex seem to be responsible for aldosterone production (108), cells were isolated from the bovine adrenal cortex, and in vitro stimulation by corticotropin and the 


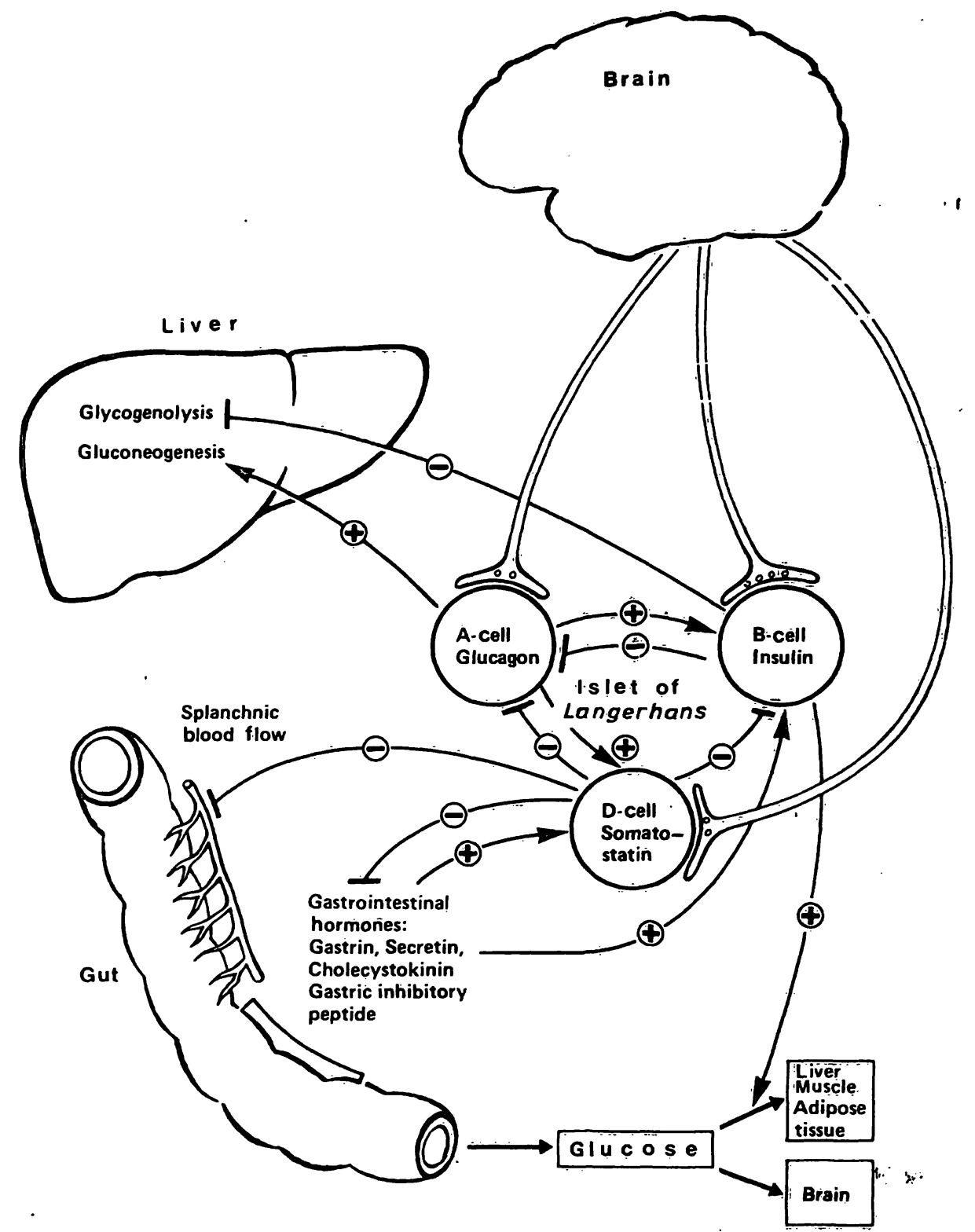

Fig. 4. Regulation of glucose homeostasis. Somatostatin may be involved in the glucose homeostatis during meals.

influence of added somatostatin were measured by aldosterone determination (109). The results indicated that the inhibitory effect of somatostatin cannot be evaluated in the bovine aldosterone-producing system in vitro.

\section{Other effects of somatostatin}

The concept that somatostatin is a general inhibitory hormone (110) cannot be applied to its effect on mast cells. Here, somatostatin causes a histamine release in vitro (114). Furthermore, in vivo studies have shown that somatostatin enforces the passive cutaneous anaphylaxis in sensitized rats at doses greater than $1 \mu \mathrm{mol} / 1$ (115).

Usadel and collaborators found that somatostatin treatment led to an increase in the survival rate in phalloidinintoxicated rats (116), and Szabo \& Usadel have postulated that this cytoprotective effect is caused via a systemic organoprotection (117) and vasculoprotection (118). The beneficial effect of somatostatin was also seen in experimental adrenal and lung injuries (119) as well as in various shock syndromes (120). The mode of these actions needs further investigation.

\section{Clinical Importance}

\section{Influence in pathogenesis}

After discovering the inhibitory effect of somatostatin on glucose and insulin, clinical studies were performed in order to evaluate the importance of this peptide in diabetes mellitus. Somatostatin lowers blood glucose levels in patients with diabetes mellitus and in normal subjects (121-123). Via the artificial pancreas somatostatin is able to reduce the requirement of insulin in more than $70 \%$ of patients with juvenile diabetes (124). Pfeiffer commented in a recent review that a selective 


\section{)ie}

'roblemlösung uf die Sie ;ewartet haben

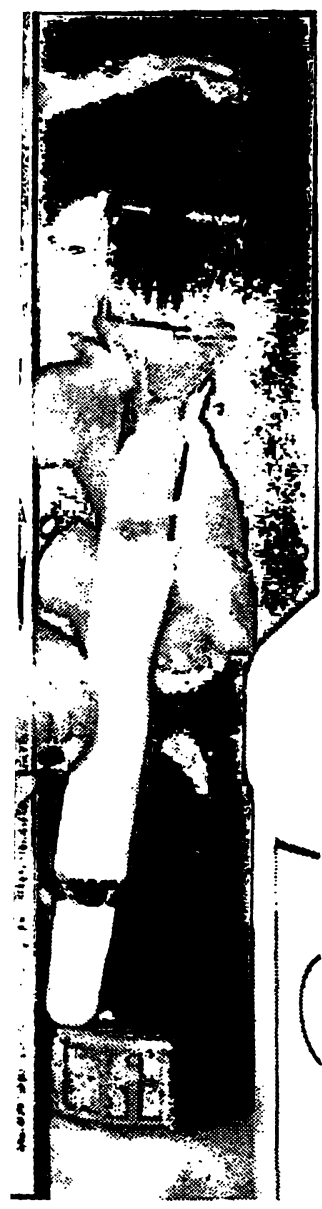

\section{IgM/IgG- Trennsystem}

Ein einfaches säulenchromatographisches Verfahren trennt IgM von IgG ab. Dadurch werden die oft auftretenden analytischen Schwierigkeiten beendet.

Der Kit wird komplett mit Wegwerfsäulen und Elutionsreagenzien - geliefert.

20 Trennungen 100 Trennungen

DM 120.DM 440,-

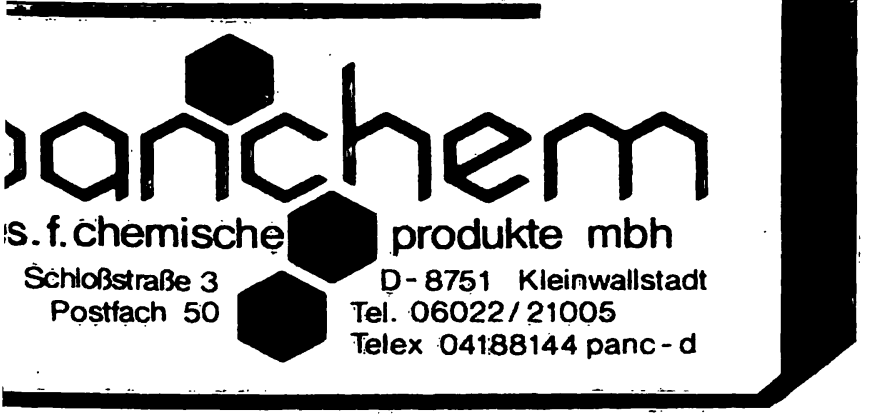

FettstoffwechselDiagnostik

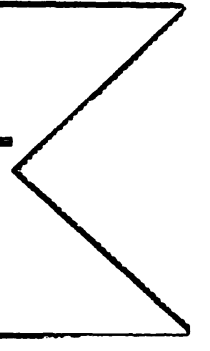

ñev 14 \& vollenzy pátische

Farbtest
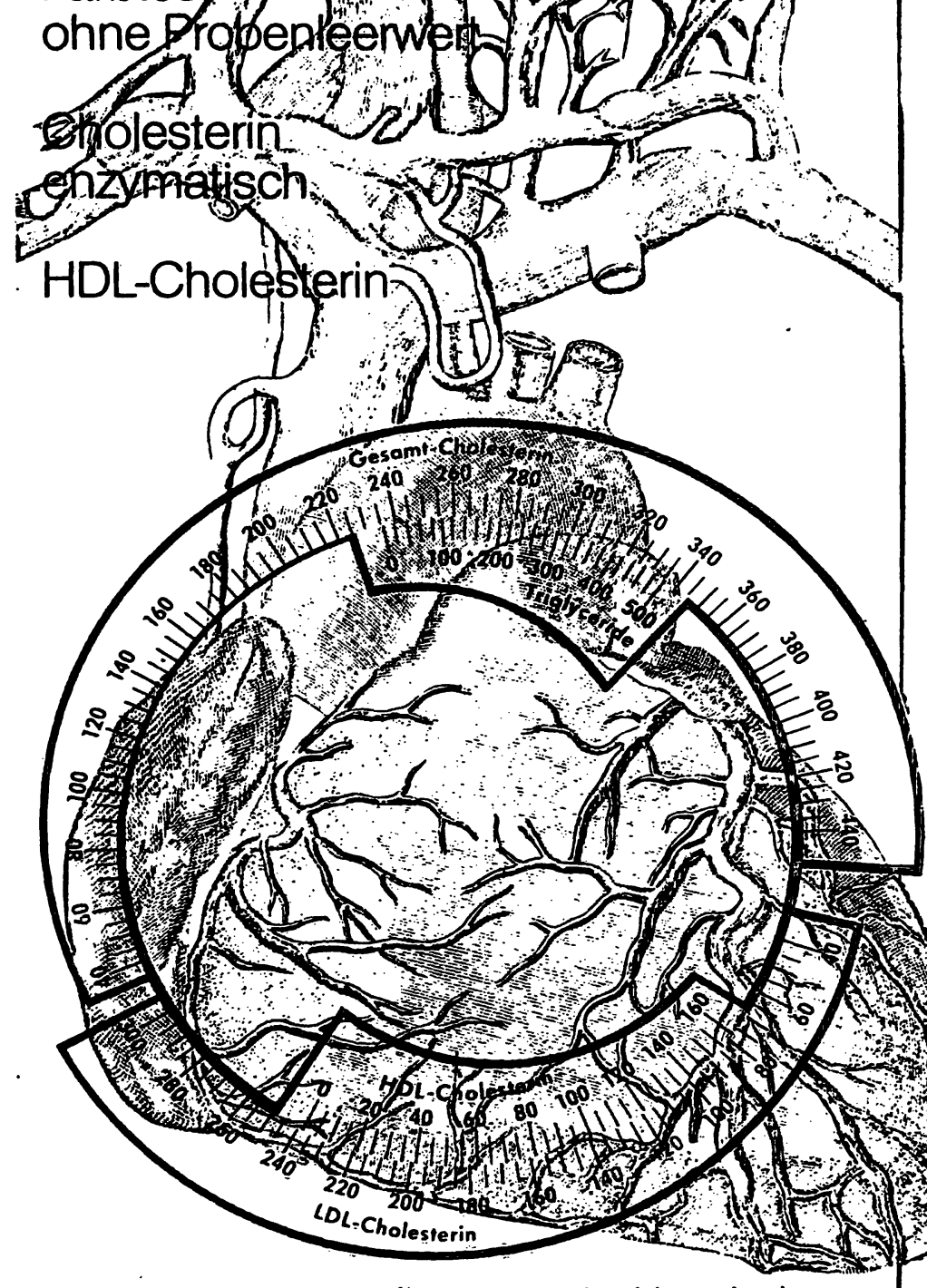

Aussagen über das Risiko arteriosklerotischer Gefäßerkrankungen sind durch die Bestimmung des Gesamtcholesterins und der Triglyceride im Serum möglich; darum sind diese beiden Bestimmungen als Basisprogramm der Lipiddiagnostik anzusehen. Die zusätzliche Bestimmung des HDLCholesterins erlaubt weitere fundierte diagnostische Aussagen.

E. Merck, V Diag W Frankfurter Straße 250 D6100 Darmstadt 1

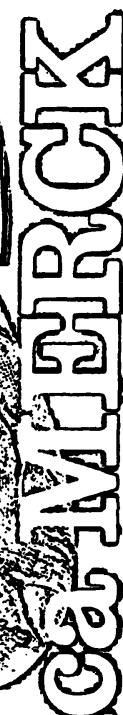




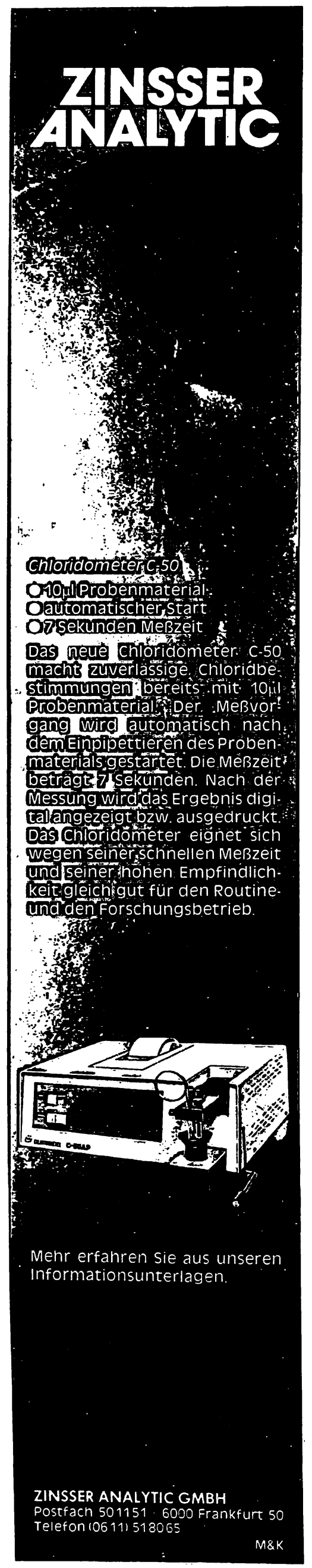

\section{W Walter de Gruyter G. Berlin.New York}

\section{E. Buddecke \\ Biochemische Grundlagen der Zahnmedizin}

$17 \mathrm{~cm} \times 24 \mathrm{~cm} . \mathrm{XV}, 193$ Seiten. 90 Abbildungen. 19 Tabellen. 1981. Flexibler

Einband. DM 36, - ISBN 3110087383

Das Kurzlehrbuch für Zahnärzté und Studierende behandelt die Biochemie der Zähne, des Zahnhalteapparates und der Mundhöhle. Es werden Chemie und Štoffwechsel der organischen Matrix der Zahnhartsubstanz, Biomineralisaation, Fluoridstoffwechsêl uñd die spezzielle Biochemie des Speichels und der Mikroorganișmen der Mundhö́hle beschrieben. Sie bilden die Grundlage für die Pathobiochèmie der beidèn häufigssten Erkrankungen der Odontologie - der Karies und der Parodontopathie. Die Darstellung umfaßt neben pathogenetischen auch präventive Aśpektēe der Karies uñd Parodontopathie sowie eine Übersicht über die chemische Zusammensetzung und Wirkungsweise von Zahnpflegemitteln.

Der behandelte Infiält des Buches berücksichtigt auch die Prüfungsordnung für Zahnärzte.

\section{Aus dem Inhalt (Hauptkapitel):}

Zahnmedizin und Biochemie - Chemie der anorganischen und organischen Bestañdtëile der Zahnhartgewebe . Stoffwechsel der organischen Matrix von Zähnen und Knochen - Biomineralisation Regulation des Hartgewebestoffwechsels - Topochemie der Zahn hartgewebe - Biochemie des Fluors . Speicheldrüsen und Speichel - Mikroorgànismen der Mundhöhle. Pathobiochemie der Karies . Kariesabwehr und Kariesprophylaxe . Gingiva, Parodont und Parodontopathie . Chemische Zusammensetzung von Zahnpflegemitteln · Mundhöhle und Allgemeinstoffwechsel. 
analogue, without the general inhibiting potency of somatostatin, could play a role in diabetes treatment (125). There is also some indication that the hormone may be involved in the pathogenesis of diabetes mellitus. In the pancreatic islets of both patients with juvenile diabetes and in rats with diabetes induced by streptozotocin, a hypertrophy and hyperplasia of D-cells containing somatostatin has been found (126). Elevated somatostatin and glucagon release were observed in isolated pancreatic islets from streptozotocin diabetic rats (127-129). D-cell hyperplasia in diabetes could be interpreted as an ineffective attempt to prevent the glucagon hypersecretion by elevated local somatostatin production (126). In the gastrointestinal tract, somatostatin inhibits gastrin secretion (89). The somatostatinproducing $D$-cells are located in close proximity to the gastrin-producing G-cells (127). In patients with duodenal ulcers, a decrease in D-cell numbers of up to $70 \%$ has been found in the mucosa $(128,129)$.

A short time after the discovery of somatostatin, its effect on patients suffering from acromegaly was tested. Several groups reported a dose-dependent fall in the plasma level of somatotropin $(74,76,78)$. However, after stopping somatostatin infusion, elevated somatotropin levels returned.

\section{Somatostatinoma}

The pancreas has a great potential for tumour formation. Most tumours are derived from the exocrine pancreas. However, an increasing number from the endocrine pancreas have been identified in the past 25 years. Recently, somatostatin-producing tumours, somatostatinomas, hâve been found in the pancreas (130137), duodenum (138), and jejunum (139). Ectopic production of somatostatin by a cultured humạn pulmonary small cell carcinoma has âlso been obșerved (140). Endocrine and exocrine pancreatic insufficiency, steatorrhea, diabetes mellitus, and cholelithiasis in the presence of a duodenal tumour suggest a somatostatinoma (134). Elevated plasma sómatostatin and immunohistochemical examination of the tumour tissue can confirm the somatostatinoma diagnosiss.

\section{Clinical Somạtoștạtin Treatment}

Using experimental ulcer models $(141,142)$, somatostatin was shown to be effective, as the permanent infusion of somatostatin in patients suffering from bleeding gastric ulcers stopped bleeding within 6 to 8 hours (143, 144).

A randomized controlled trial showed somatostatin to be more effective than cimetidine in stopping the bleeding from a peptic ulcer (145).

Acute pancreatitis is also a conceivable candidate for somatostatin treatment. In experimentally induced haemorrhagic pancreatitis in dogs, somatostatin caused a remarkable reduction in the clinical symptoms (146). Prophylactic infusion of somatostatin before the start of an operation on the pancreas reduced the postoperative complications (147). Also, two studies have shown an impressive recovery from acute pancreatitis after treatment with somatostatin $(148,149)$. For further investigation on somatostatin treatment in acute pancreatitis, a multicentre double-blind trial was started in 1980. The results will be reported in 1982 (150).

\section{Detection of Somatostatin}

If a clinician is presented with a tumour which produces neither insulin, gastrin, nor glucagon, it is recommended by the German Endocrine Society that the plasma levels of somatostatin be measured (151).

Several radioligand binding assays for somatostatin measurement have been described $(49,50,152-162)$. Normal somatostatin plasma levels in man are in the range of $40 \mathrm{ng} / \mathrm{l}(50)$. With immunohistochemical methods, e.g., peroxidase-antiperoxidase technique $(163,164)$, somatostatin can be detected in the tissue. The distribution of somatostatin in the pancreatic islet is shown in figure 5.

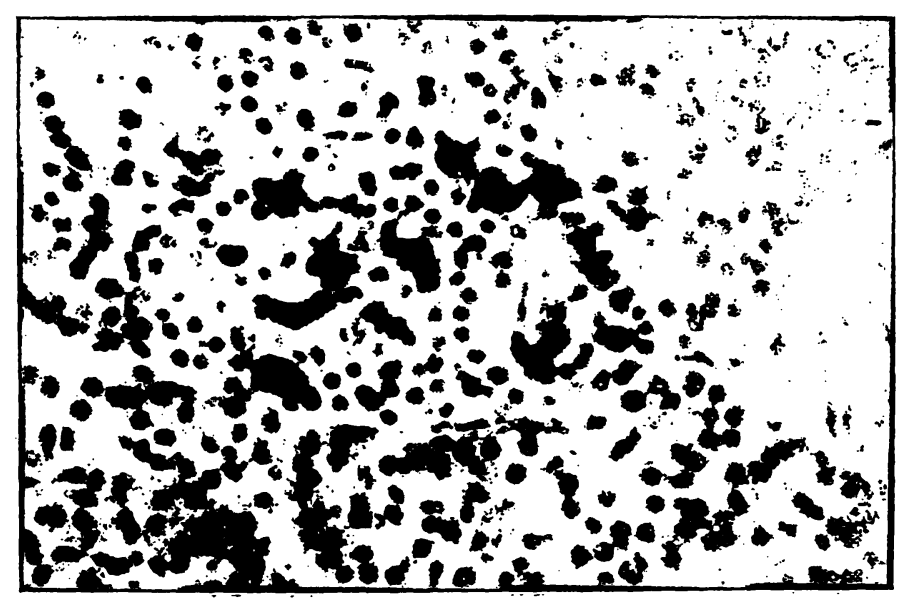

Fig. 5. Numerous somatostatin cells (D-cells) are present in the islet of Langerhans. Human pancreas section incubated with antisomatostatin serum (153). Sites of antibody attachment visualized with diaminobenzidine usually appear dark (peroxidase-anti-peroxidase technique, Bethge (164). Magnification: 260X.

\section{Conclusion}

Somatostatin is involved in the regulation of somatotropin secretion in the pituitary and may play a fundamental role in glucose homeostatis and assimilation of nutrients. At the present time, little is known about the action of somatostatin in the central nervous system (165). 
The peptide has a beneficial effect in a variety of illnesses, in particular, bleeding gastric ulcers and various experimental organ lesions, e.g., liver, lung, adrenal and shock syndromes.

It is likely that the numerous regulatory effects of the peptide will only be properly integrated and understood when the events occurring in the cell after the ligandreceptor interaction are better known at a molecular level.

\section{References}

1. Burgus, R., Dunn, T. F., Desiderio, D. \& Guillemin, R. (1969) C. R. Acad. Sci. (D) (Paris) 269, 1870-1873.

2. Böer, J., Enzmann, F., Folkers, K., Bowers, C. Y. \& Schally, A. V. (1969) Biochem. Biophys. Res. Commun. 37, 705-710.

3. Baba, Y., Matsuo, H. \& Schally, A. V. (1971) Biochem. Biophys. Res. Commun. 44, 459-463.

4. Brazeau, P., Vale, W., Burgus, R., Ling, N., Butcher, M., Rivier, J. \& Guillemin, R. (1973) Science 179, 77-79.

5. Schally, A. V., Dupont, A., Arimura, A., Redding, T. W., Nishi, N., Linthicum, G. L. \& Schlesinger, D. H. (1976) Biochemistry 15, 509-514.

6. Bower, C. Y., Friesen, H., Hwang, P., Guyda, J. J. \& Folkers, K. (1971) Biochem. Biophys. Rès. Cómmun. 45, 1033-1041.

7. Schally, A. V., Arimura, A. \& Kastin, A. J. (1973) Science 179, 341-350.

8. Vale, W., Brazeau, P., Rivier, C., Rivier, J., Grant, G., Burgus, R. \& Guillemin, R. (1973) Fed. Proc. 32, 211.

9. Luft, R., Efendic, S., Hökfelt, T., Johansson, O. \& Arimura, A. (1974) Med. Biol. 52, 428-430)

10. Hökfelt, T., Efendic, S., Hellerström, C., Johansson, O., Luft, R. \& Arimura, A. (1975) Acta Endocrinol. (Kbh.) 80 , S. $200,5-41$.

11. Polak, J. M., Grimelius, L., Pearse, A. G. E., Bloom, S. R. \& Arimura, A. (1975) Lancet II, 1220-1222.

12. Rufener, C., Amherdt, M., Dubois, M. P. \& Orci, L. (1975) J. Histochem. Cytochem. 23, 866-869.

13. Arimura, A., Sato, H., Dupont, A., Nishi, N. \& Schally, A. V. (1975) Science 189, 1007-1009.

14. Pradayrol, L., Chayvialle, J. A., Caklquist, M. \& Mutt, V. (1978) Biochem Biophys. Res. Commun. 85, 701-708.

15. Pradayrol, L., Jörnvall, H., Mutt, V. \& Ribet, A. (1980) FEBS-Lett. 109, 55-58.

16. Lehy, T., Peranzi, G. \& Cristina, M. L. (1981) Histochemistry 71, 67-80.

17. Morley, J. F., Garvin, T. J., Pekary, A. E. \& Hershman, J. M. (1977) Biochem. Biophys. Res. Commun. 79, 314-318.

18. Eulèr, U. S. von \& Gaddum, J. H. (1931) J. Physiol. (Lond.) $72,74-87$

19. Polak, J. M. \& Bloom, S. R. (1979) Wld. J. Surg. 3, 393406.

20. Mutt, V. \& Said, S. I. (1974) Europ. J. Biochem. 42, 581589.

21. Said, S. I. \& Rosenberg, R. N. (1976) Science 192, $907-$ 908.

22. Carraway, R. \& Leeman, S. E. (1976) J. Biol. Chem. 251, 7045-7052.

23. Rehfeld, J. F. (1978) Nature (Lond.) 271, 771-773.

24. Havrankova, J., Schmechel, D., Roth, J. \& Brownstein, M. (1978) Proc. Nat. Acad. Sci. (USA) 75, 5737-5741.

25. Johansson, O. (1978) Histochemistry $58,167-176$.

26. Luft, R., Efendic, S. \& Hökfelt, T. (1978) Diabetologia 14, $1-13$.

27. Pearse, A. G. E. (1980) in: Clinics in Endocrinology and Metabolism (Abe, K., ed.) p. 211-222. Saunders Company, London-Philadelphia-Toronto.

28. Melani, F. (1974) Horm. Metab. Res. 6, 1-8.

29. Zülke, H., Ziegler, M., Jahr, H., Titze, R. \& Schmidt, S. (1978) Acta Biol. Med. Germ. 37, K15-K18.

\section{Acknowledgments}

The authors wish to thank Dr.M. Isla Halliday, Queen's University Belfast; Professor Dr. Dr. S. Szabo, Brigham and Women's Hospital, and Harvard Medical School, Boston (MA 02115, USA), Professor Dr. B. Press and Dr. H. Pickartz, Institut für Pathologie, Universitätsklinikum Steglitz, Freie Universität Berlin for their very helpful advice.

We also thank Mrs. Marion Allert and Miss Ursula Schulz for expert assistance in immunohistochemistry.

30. Noe, B. D., Weir, G. C. \& Bauer, G. E. (1978) Metabolism 27, S1, 1201-1205.

31. Ensinck, J. W., Laschansky, E. C., Kanter, R. A., Fuji= moto, W. Y., Koerker, D. J. \& Goodner, Ch. J. (1978) Metabólism 27, S1, 1207-1210.

32. Lingappa, V. R. \& Blobel, G. (1980) Recent Progì. Hormone Res. 36, 451-475.

33. Böhlen, P., Brazeau, P., Benoit, R., Ling, N., Esch, F. \& Guillemin, R. (1980) Biochem. Biophys. Res. Commun. 96, 725-734.

34. Schally, A. V., Huang, W.-Y., Chang, R. C. C., Arimua, A. Redding, T. W., Millar, R. P., Hükapiller, M. W. \& Hood, L. E. (1980) Proc. Natl. Acad. Sci. (USA) 77, 4489-4493

35. Millar, R. P., Wegner, I., Michie, J. and Kewley, C. (1982) in: 2nd Internat. Symp. Somatostatin (Raptis, S., èd.) Academic Press, N.Y. in press.

36. Michie, J., Millar, R. \& Schally, A. V. (1982) in: 2nd Internat. Symp. Somatostatin (Raptis, S., ed.) Academic Press, N.Y. in press.

37. Hobart, P., Crawford, R., Shen, L.-P., Pictet, R. \& Rutter, W. J. (1980) Nature (Lond.) 288, 137-141.

38. Goodman, R. H., Lund, P. K., Jacobs, J. W. \& Habener, J. F. (1980) J. Biol. Chem. 255, 6549-6552.

39. Goodman, R. H., Jacobs, J. W., Chin, W. W., Lund, P. K., Dee, P. C. \& Habener, J. F. (1980) Proc. Natl. Acad. Sci. (USA) 77, 5869-5873.

40. Shields, D. (1980) J. Biol. Chem. 255, 11625-11628.

41. Lauber, M., Camiep, M. \& Cohen, P. (1979) Proc. Natl. Acad. Sci (USA) 76, 6004-6008.

42. Spiess, J. \& Vale, W. (1980) Biochemistry 19, $2861-2866$.

43. Morel, A., Lauber, M. \& Cohen, P. (1981) FEBS-Lett. 136, $316-318$.

44. Bauer, K. \& Nowak, P. (1979) Ëurop. J. Biochem. 99, $239-246$.

45. Knisatschek, H. \& Bauer, K. (1979) J. Biol. Chem. 254, 10936-10943.

46. Horsthemke, B. \& Bauer, K. (1980)Biochemistry 19 , 2867-2873.

47. Marks, N. \& Stern, F. (1975) FEBS-Lett. 55, 220-224.

48. Verber, D. F., Holly, F. W., Nutt, R. F., Bergstrand, S. J., Brady, S. F. \& Hirschmann, $\vec{R}$. (1979) Nature (Lond.) $280,512-514$

49. Bethge, N., Diel, F., Rösick, M., Holz, J., Thomsen, P. D. \& Quabbe, H.-J. (1980) J. Clin. Chem. Clin. Biochem. 18, 734.

50. Bethge, N., Diel, F., Rösick, M. \& Holz̀, J. (1981) Horm. Metab. Res. 13, 709-710.

51. Sheppard, M., Shapiro, B., Pimstone, B., Kroñheim, S., Berelowitz, M. \& Gregory, M. (1979) J. Clin. Ëndocrinol. Metab. 48, 50-53.

52. Patel, Y. C. \& Wheatley, T. (1982) in: 2nd Internat. Symp. Somatostatin (Raptis, S., ed.) Academic Press, N.Y. in press.

53. McMartin, C. \& Pürdon, G. (1978) J. Endocrinol. 777, 6774.

54. McMartin, C. \& Peters, G. (1982) in: 2nd Internat. Symp. Somatostatin (Raptis, S., ed.) Academic Press, N.Y. in press.

55. Meyers, C. A., Murphy, W. A., Redding, T. W., Coy, D. H. \& Schally, A. V. (1980) Proc. Natl. Acad. Sci. (USA) 77, 6171-6174. i: 
56. Hatzidakis, D., Raptis, S., Souvatzoglou, A., Karaiskos, K., Axarlis, K., Zoupas, Ch., Diamantopoulos, E. \& Moulopoulos, S. (1982) in: 2nd Internat. Symp. Somatostatin (Raptis, S., ed.) Academic Press, N.Y. in press.

57. Rodriguez-Arnao, M. D., Gomez-Pan, A., Rainbow, S. J., Woodhead, S., Owens, D. R., Schally, A. V. \& Hall, R. (1982) in: 2nd Internat. Symp. Somatostatin (Raptis, S., ed.) Academic Press, N.Y. in press.

58. Schonbrunn, A. \& Tashjian Jr., A. H. (1978) J. Biol. Chem. $253,6473-6483$.

59. Schonbrunn, A. \& Tashjian Jr., A. H. (1980) J. Biol. Chem. $255,190-198$.

60. Kahn, C. R. (1976) J. Cell. Biol. 70, 261-286.

61. Leitner, J. W., Rifkin, R. M., Maman, A. \& Sussman, K. E. (1979) Biochem. Biophys. Res. Commun. 87, 919-927.

62. Srikant, C. B. \& Patel, Y. C. (1981) Endoctinology 108, $341-343$.

63. Srikant, C. B. \& Patel, Y. C. (1982) in: 2nd Internat Symp. Somatostatin (Raptis, S., ed.) Academic Press, N.Y. in press.

64. Diel, F., Schneider, E. \& Quabbe, H.-J. (1977) XI Acta Endocrinologica Congress (Lausanne) Abstr. 439.

65. Diel, F., Bethge, N., Schneider, E. \& Quabbe, H.-J. (1981) J. Clin. Chem. Clin. Biochem. 19, 99-107.

66. Ogawa, N., Thompson, T., Friesen, H. G., Martin, J. B. \& Brazeau, P. (1977) Biochem. J. 165, 269-277.

67. Mehler, P. S., Sussmann, A. L., Maman, A., Leitner, J. W. \& Sussmann, K. E. (1980) J. Clin. Invest. 66, 1334-1338.

68. Borgeat, P., Labrie, F., Drouin, J., Belanger, A., Immer, H., Sestanj, K., Nelson, V., Götz, M., Schally, A. V., Coy, D. H. \& Coy, E. J. (1974) Biochem. Biophys. Res. Commun. $56,1052-1059$.

69. Effendic, S. \& Luft, R. (1975) Acta Endocrinol. (Kbh.) 78 $510-515$.

70. Kaneko, T., Oka, H., Munemura, M., Suzuki, S., Yasuda, H., Oda, T. \& Yanaihara, N. (1974) Biochem. Biophys. Res. Commun. 61, 53-57.

71. Sussmann, A. L., Leitner, J. W. \& Rifkin, R. M. (1978) Trans. Ass. Amer. Physicians 91, 129-143.

72. Siler, T. M., van den Berg, G., Yen, S. S. C., Brazeau, P., Vale, W. \& Guillemin, R. (1973) J. Clin. Endocrinol. Metab. 37, 632-634.

73. Peracchi, M., Reschini, E., Cantalamessa, L., Guistina, G., Cavagnini, F., Pinto, M. \& Bulgheroni, P. (1974) Metabolism 23, 1009-1015.

74. Hạll, R., Besser, G. M., Schally, A. V., Coy, D. H., Evered, D., Goldie, D. J., Kastin, A. J., McNeilly, A. S., Mortimer, C. H., Phenekos, C., Tunbridge, W. M. G. \& Weightman, D. (1973) Lancet $I \bar{I}, 581-584$

75. Parker, D. C., Rossman, L. G., Siler, T. M., Rivier, J., Yen, S. S. C. \& Guillemin, R. (1974) J. Clin. Endocrinol. Metab. 38, 496-499.

76. Mortimer, C. H., Tunbridge, W. M. G., Cart, D., Yeomans, L., Lind, T., Coy, D. H., Bloom, S. R., Kastin, A., Mallinson, C. N., Besser, G. M., Schally, A. V. \& Hall, R. (1974) Lancet $I, 697-701$.

77. Vale, W., Rivier, C., Brazeau, P. \& Guillemin, R. (1974) Endocrinólogy 95, 968-977.

78. Yen, S. S. C., Silex, T. M. \& de Vane, G. W. (1974) N. Engl. J. Med. 290, 935-938.

79. Lucke, C., Mitzkat, H. J. \& Mühlen, A. von zuir (1976) Klin. Wochenschr. 54, 293-301.

80. Tyrrell, J. B., Lorenzi, M., Gerich, J. E. '\& Forsham, P. H. (1975) J. Clin. Endocrinol. Metab: 40, 1125-1127.

81. Benker, G., Hackenberg, K., Hamburger, B. \& Reinwein, D. (1976) Clin. Endocrinol. (Oxf.) 5, 187-190.

82. Fehm, H. L., Voigt, K. H., Lang, R., Beinert, K. E., Raptis, S. \& Pfeiffer, E. F. (1976) Klin. Wochenschr. 54, 173175 .

83. Alberti, K. G. M. M., Christensen, N. J., Christensen, S. E., Hansen, A. P., Iversen, J., Lundbaek, K., Seyer-Hansen, K. \& Orskov, H. (1973) Lancet II, 1299-1301.

84. Ruch, W., Koerker, D., Carino, M., Johnsen; S., Webster, B., Ensinck, J., Goodner, C. \& Gale, C. (1973) in: Advances in human growth hormone research (Raiti, S., ed.) DHEW Publ. No. (NIH) 74-612, US Govt. Printing Office, Washington.
85. Koerker, D. J., Ruch, W., Chideckel, G., Palmer, J., Goodner, C., Ensinck, J. E. \& Gale, C. (1974) Science 184, $482-484$

86. Gerich, J. E., Lorenzi, M., Hane, S., Gustafson, G., Guillemin, R. \& Forsham, P. H. (1975) Metabolism 24, 175-182.

87. Orci, L., Baetens, D., Ravazzola, M., Stefan, Y. \& MalaisseLagae, F. (1976) Life Sci. 19, 1811-1816.

88. Floyrd, J. C., Fajans, S. S., Pek, S. \& Chance, R. E. (1977) Rec. Progr. Horm. Res. 33, 519-570.

89. Bloom, S. R., Mortimer, C. H., Thorner, M. O., Besser, G. M., Hall, R., Gomez-Pan, A., Roy, V. M., Russell, R. C. G., Coy, D. H., Kastin, A. J. \& Schally, A. V. (1974) Lancet II, $1106-1109$.

90. Classen, M. \& Huber, M. (1977) Innere Medizin 4, 262-266.

91. Gomez-Pan, A., Reed, J. D., Albinus, M., Shaw, B., Hall, R., Besser, G. M., Coy, D. H., Kastin, A. J. \& Schally, A. V. (1975) Lancet $I, 888-890$.

92. Creutzfeldt, W., Lankisch, P. G. \& Fölsch, U. R. (1975) Dtsch. Med. Wochenschr. 100, 1135-1138.

93. Boden, G., Sivitz, M. C., Owen, O. E., Essa-Koumar, N. \& Landor, J. H. (1975) Science 190, 163-165.

94. Bloom, S. R., Ralphs, D. N., Besser, G. M., Hall, R., Coy, D. H., Kastin, A. J. \& Schally, A. V. (1975) Gut 16, 834.

95. Lennon, J. R., Sircos, W., Bloom, S. R., Mitchell, S. J., Polak, J. M., Besser, G. M., Hall, R., Coy, D. H., Kastin, A J. \& Schally, A. V. (1975) Gut 16, 821-822.

96. Efendic, S., Nylen, A., Roovete, A. \& Uvnaes-Wallenstein, K. (1978) FEBS-Lett. 92, 33-35.

97. Ipp, E., Dobbs, R. E., Arimura, A., Vale, W., Harris, V. \& Unger, R. H. (1977) J. Clin. Invest. 60, 760-765.

98. Patton, G. S., Ipp, E., Dobbs, R. E., Orci, L., Vale;W. \& Unger, R. H. (1976) Life Sci. 19, 1957-1959.

99. Schaunder, P., McIntosh, C., Arends, J., Arnold, R., Frerichs, H. \& Creutzfeldt, W. (1977) Biochem. Biophys. Res. Commun. 75, 630-635.

100. Boden, G., Jacoby, H. I. \& Staus, A. (1976) Gastroenterology 70,961 .

101. Wahren, J. \& Felig, P. (1976) Schweiz. Med. Wochenschr. $109,595-596$.

102. Keller, U., Sonnenberg, G. E., Kayasseh, L., Gyr, K. \& Perruchoud, A. (1979) Schweiz. Med. Wochenschr. 109, 595-596.

103. Samnegrad, H., Tyden, G., Thulin, L., Friman, L. \& Uden, R. (1980) Acta Chir. Scand. S. 500, 71-73.

104. Doertenbach, J. G., Hottenrott, Ch., Seufert, R. M., Schwedes, U. \& Usadel, K. H. (1982) in: 2nd Internat. Symp. Somatostatin (Raptis, S., ed.) Aicademic Press, N.Y., in press.

105. Gomez-Pan, A., Snow, M. H., Piercy, D. A., Robson, V., Wilkinson, R., Hall, R., Evered, D. C., Besser, G. M., Schally, A. V., Kastin, A. J. \& Coy, D. H. (1976) J. Clin. Metab. 43, 240-243.

106. Rosenthal, J., Raptis, S., Zoupas, C. \& Escobar-Jomenez, F. (1978) Circ. Res. 43, S 1, 69-76.

107. Schölkens, B. A. (1978) Arzneim.-Forsch. 28, 802-803.

108. Haning, R., Tait, S. A. \& Tait, J. F. (1970) Endocrinology $87,1147-1167$

109. Diel, F., Holz, J. \& Bethge, N. (1981) Horm. Metab. Res. $13,95 \div 98$.

110. Guillemin, R. (1978) Metabolism 27, S1, 1453-1461.

111. Baxter, J. H. \& Adamik, R. (1978) Biochem. Pharmacol. 27, 497-503.

112. Theoharides, T. C. \& Douglas, W. W. (1978) Endocrinology $102,1637-1640$.

113. Diel, F., Vangala, R. R., Neidhart, B. \& Antweiler, H. (1980) Toxicol. Lett. S1, 205.

114. Bethge, N., Diel, F. \& Jautzke, G. (1981) Verh. Dt. Gesell. Pathol. 65, 484.

115. Diel, F., Tönnies, G. \& Bethge, N. (1982) in: 2nd In ternat. Symp. Somatostatin (Raptis, S., ed.) Academic Press, N.Y., in press.

116. Wdowinski, J. M., Schwedes, U., Faulstich, H., Dancygier, H., Leuschner, U., Siede, W. H., Hübner, K., Schöffling, K. \& Usadel, K. H. (1981) Res. Exxp. Mèd. (Berl.) 178, $155-163$.

117. Szabo, S. \& Usadel, K. H. (1980) Experientia 38, 254-256. 
118. Szabo, S. \& Usadel, K. H. (1982) in: 2nd Internat. Symp. Sornatostatin (Raptis, S., ed.) Academic Press, N.Y., in press.

119. Schwedes, U., Szabo, S. \& Usadel, K. H. (1978) Metabolism $27 \mathrm{~S} 1,1377-1380$.

120. Schwedes, U., Wdowinski, J., Althoff, P. H. \& Usadel, K. H. (1980) Acta Endocrinol. (Kbh) S. 234, 142-143.

121. Gerich, J. E., Lorenzi, M., Schneider, V., Kwan, C. W., Karam, M., Guillemin, R. \& Forsham, P. H. (1974) Diabetes $23,876-880$.

122. Tragel, K. H., Pointer, H., Kinast, H., Flegel, U. \& Deutsch, E. (1976) Wien. Klin. Wochenschr. 88, 530-532.

123. Luyckx, A. S. \& Lefebvre, P. J. (1976) Diabetologica 12, 447-453.

124. Meissner, C., Thum, C. H., Beischer, W., Winkler, G., Schroder, K. E. \& Pfeiffer, E. F. (1975) Diabetes 24, 988 996.

125. Pfeiffer, E. F. (1981) Internist 22, 229-241.

126. Orci, L., Baetens, D., Rufener, C., Amherot, M., Ravazzola, M., Studer, P., Malaisse-Lagae, F. \& Unger, R. H. (1976) Proc. Natl. Acad. Sci (USA) 73, 1338-1342.

127. Larsson, L. I., Goltermann, N., Magistris de, L., Rehfeld, J. F. \& Schwartz, T. W. (1979) Science 205, 1393-1395.

128. Polak, J. M., Bloom, S. R., Bishop, A. E. \& McCrossan, M. V. (1978) Metabolism 27, S1, 1239-1242.

129. Polak, J. M., Bloom, S. R., McCrossan, M., Timson, C. M. \& Arimura, A. (1976) Gut 17, 400-401.

130. Ganda, O. P., Weir, G. C., Soeldner, J. S., Legg, M. A., Chick, W. L., Patel, Y. C., Ebeid, A. M., Igabbay, K. H. \& Reichlin, S. (1977) N. Engl. J. Med. 296, 963-967.

131. Kovacs, K., Horvath, E., Ezrin, C., Sepp, H. \& Elkar, I. (1977) Lancet $I, 1365-1366$.

132. Galmiche, J. P., Colin, R., Dubois, P. M., Chayvialle, J. P. Descos, F., Paulin, C. \& Geffroy, Y. (1978) New. Engl. J. Med. 299, 1252.

133. De Nutte, N., Somer, G., Gepts, W. \& Pipeleers, D. (1978) Diabetologia 15, 227.

134. Krejs, G. J., Orci, L., Conlon, J. M., Ravazzola, M., Davis, G. R., Raskin, P., Collins, S. M., McCarthy, D. M., Baetens, D., Rubenstein, A., Ialdor, T. A. M. \& Unger, R. H. (1979) N. Engl. J. Med. 301, 285-292.

135. Galmiche, J. P., Chayvialle, J. A., Dubois, P. M., David, L., Descos, F., Paulin, C. \& Geffroy, Y. (1978) N. Engl. J. $299,1252$.

136. Lowry, S. F., Burt, M. E. \& Brennan, M. F. (1981) Surgery $89,309-313$.

137. Axelrod, L., Bush, M. A., Hirsch, H. J. \& Loo, S. W. H. (1981) J. Clin. Endocrinol. Metab. 52, 886-896.

138. Kaneko, H., Yanaihara, N., Ito, S., Kusumoto, Y., Fujita, T., Ishikawa, S., Sumida, T. \& Sekiya, M. (1979) Cancer $44,2273-2279$.

139. Alumets, J., Ekelund, G., Hakanson, R., Ljungberg, $O$. Ljungqvist, U., Sundler, F. \& Tibblin, S. (1978) Virchows Arch. A. (Pathol. Anat.) 378, 17-22.

140. Szab, M., Berelowitz, M., Pettengill, O. S., Sorenson, G. D. \& Frohman, L. A. (1980) J. Clin. Endocrinol. Metab. 51, 978-987.

141. Schwedes, U., Usadel, K. H. \& Szabo, S. (1977) Europ. J. Pharmacol. 44, 195-196.

142. Schwille, P. O., Putz, F., Thun, R., Schellerer, W., Draxler, G. \& Lang, G. (1977) Acta Hepato-Gastroenterol. 24, 259 265.

143. Mattes, P., Raptis, S., Heil, Th., Rasche, H. \& Scheck, R. (1975) Horm. Metab. Res. 7, 508-511.

144. Kayasseh, L., Gyr, K., Stalder, G. A. \& Allgöwer, M. (1978) Schweiz. Med. Wochenschr. 108, 1083-1084.

145. Kayasseh, L., Gyr, K., Keller, U., Stalder, G. A. \& Wall, M. (1980) Lancet $I, 844-846$.

146. Schwedes, U., Althoff, P. H., Klempla, I., Leuschner, U., Mothes, L., Raptis, S., Wdowinski, J. \& Üsadel, K. H. (1979) Horm. Metab. Res. 11, 655-661.

147. Klempa, I., Schwedes, U. \& Usadel, K. H. (1979) Chirurg $50,427-431$.

148. Limberg, B. \& Kommerell, B. (1980) N. Engl. J. Med. 303, 284

149. Usadel, K. H., Schwedes, U., Wdowinski, J., Althoff, P. H., Raptis, S., Klempla, I., Strohm, W. D. \& Leuschner, U. (1979) Verh. Dtsch. Ges. Inn. Med. 85, 591.
150. Usadel, K. H., Leuschner, U. \& Uberla, K. K. (1980) N. Engl. J. Med. 303, 999.

151. Arnold, R., Fritsch, W.P., Londong, W., Schafmeyer, A. \& Schusdziarra, V. (1980) Endokrinol.-Inform. 4, 96-99.

152. Arimura, A., Lundqvist, G., Rothman, J., Chang, R., Fernandez-Durango, R., Coy, D. H., Meyer, C. \& Schally, A. V. (1978) Metabolism 27 S1, 1139-1144.

153. Diel, F., Schneider, E. \& Quabbe, H.-J.'(1977) J. Clin. Chem. Clin. Biochem. 15, 669-677.

154. Arimura, A., Satō, H., Coy, D. H. \& Schally, A. V. (1975) Proc. Soc. Exp: Biol. Med. 148, 784-789.

155. Dupont, A., Coy, D. H., Alvarado-Urbina, G., Cote, J., Meyers, C. A., McManus, J., Barden, N., de Lean, A. \& Labrie, F. (1979) Clin. Endöcrinol. 10, 47-54.

156. Harris, V., Conlon, J. M., Srikant, C. B., McCorkle, K., Schusdziarra, V., Ipp, E. \& Unger, R. H. (1978) Clin. Chim. Acta 87, 275-283.

157. Gerich, J., Greene, K., Hara, M., Rizza, R. \& Patton, G. (1979) J. Lab. Clin. Med. 93, 1009-1017.

158. Penman, E., Wass, J. A. H., Lund, A., Lowry, P. J., Stewart, J., Dawson, A. M., Besser, G. M. \& Ress, L. H. (1979) Ann. Clin. Biochem. 16, 15-25.

159. Lundqvist, G., Gustavsson, S., Elde, R. \& Arimura, A. (1980) Clin. Chim. Acta 101, 183-191.

160. Tsuda, K., Sakựai, H., Seino, Y., Seino, S., Tanigawa, K., Kuzuya, H. \& Imura, H. (1981) Diabetes 30, 471 474.

161. Engelhardt, W. \& Schwille, P. O. (1981) Horm. Metab. Res. 13, 318-323.

162. Diel, F. \& Betghe, N. (1981) J. Cliñ. Chem. Cliṇ. Biochem. 19,652 .

163. Sternberger, L. A., Hardy, Jr. P. H., Cuculis, J. J. \& Meyer, H. G. (1970) J. Histochem. Cytochem. 18, 315-333.

164. Bethge, N. (1982) Med. Diss., Freie Universität Berlin 913.

165. Renaud, L. P., Martin, J. B. \& Brazeau, P. (1975) Nature (Lond.) 255, 233-235.

166. Burgus, R., Ling, N., Butcher, M. \& Guillemin, R. (1973) Proc. Natl. Acad. Sci. (USA) 70; 684-688.

167. Hökfelt, T., Efen đic, S., Johansson, O., Luft, R. \& Arimura, A. (1974) Brain Res. 80, 165-169.

168. Alpert, L. C., Bräwer, J. R., Patel, Y. C. \& Reichlin, S. (1976) Endocrinology 98, 255-258.

169. Dube, D., Leclerc, R., Pelletier, G., Arimura, A. \& Schally, A. V. (1975) Cell Tissue Res. 161, 385-392.

170. King, J. C., Arimura, A., Gerall, A. A., Fischback, J. B. \& Elkind, K. E. (1975) Cell Tissue Res. 160, 423-430.

171. Pelletier, G., Leclerc, R., Dube, D., Labrie, F., Puviane, R., Arimura, A. \& Schally, A. V. (1975) Amer. J. Anat. 142, $397-401$

172. Setalo, G., Vigh, S., Schally, A. V., Arimura, A. \& Flèro, B. (1975) Brain Res. 90, 352-356.

173. Brownstein, M. J., Arimura, A., Sato, H., Schally, A. V. \& Kizer, J. S. (1975) Endocrinology 96, 1456-1461.

174. Patel, Y. C., Zingg, H. H. \& Dreifuss, J.-J. (1977) Nature (Lond.) 267, 852-853.

175. Patel, Y. C. \& Reichlin, S. (1978) Endocrinology 102, $523-530$.

176. Pevet, P., Ebels, I., Swaab, D. F., Mud; M. T. \& Ar̈imurä, A. (1980) Cell Tissue Res. 206, 341-353.

177. Shapiro, B., Krohnheim, S. \& Pimstone, B. (1979) Horm. Metab. Res. 111, 79-80.

178. Krisch, B. \& Leonhardt, H. (1979) Cell Tissue Res. 204 $127-140$.

179. Yamada, T., Marshak, D., Basinger, S., Walsh, J., Morley, J. \& Stell, W. (1980) Proc. Natl. Acad. Sci. (USA) 77, $1691-1695$.

180. Hökfelt, T., Elde, R., Johansson, O., Luft, R., Nilsson, G. \& Arimura, A. (1976) Neuroscience 1, 131-136.

181. Forssmann, W. G. (1978) Neurosci. Lett. 10, 293-297.

182. Burnweit, C. \& Forssmann, W. G. (1979) Cell Tissue Res. 200, 83-90.

183. Hökfelt, T., Elfvin, L. G., Elde, R., Schultzberg, M., Goldstein, M. \& Luft, R. (1977) Proc. Natl. Acad. Sci. (USA) $74,3587-3591$

184. Costa, M., Patel, Y. C., Fưness, J. B.\&\& Arimura, A. (1977) Neurosci. Lett. 6, 215-222: : 
185. Elde, R., Hökfelt, T., Johansson, O., Schultzberg, M., Efendic, S. \& Luft, R. (1978) Metabolism 27, S1 1151 1159.

186. Dubois, P. M., Paulin, C., Assan, R. \& Dubois, M. P. (1975) Nature (Lond.) 256, $731-732$.

187. Orci, L., Baetens, D., Dubois, M. P. \& Rufener, C. (1975) Horm. Metab. Res. 7, 400-402.

188. Parsons, J., Erlandsen, S., Hegre, O., McEvoy, R. \& Elde, R. P. (1976) J. Histochem. Cytochem. 24, 872-882.

189. Forssmann, W. G., Helmstaedter, V., Metz, J., Mühlmann, G. \& Feurle, G. E. (1978) Metabolism 27, S1, 1179-1191

190. Spiess, J., Rivier, J., Rodkey, J., Bennett, C. \& Vale, W. (1979) Proc. Natl. Acad. Sci. (USA) 76, 2974-2978.

191. Noe, B. D., Spiess, J., Rivier, J. E. \& Vale, W. (1979) Endocrinology 105, 1410-1415.

192. Oyama, H., Bradshaw, R. A., Bates, O. J. \& Permutt, A. (1980) J. Biol. Chem. 255, 2251-2254.

193. Noorden, S. V., Polak, J. M. \& Pearse, A. G. E. (1977) Histochemistry 53, 243-247.

194. Buffa, R., Chayvialle, J. A. Fontana, P., Usellini, L., Capella, C. \& Solcia, E. (1979) Histochemistry 62, 281-288.

195. Sundler, F., Alumets, J., Hakanson, R., Björklund, L. \& Ljungberg, O. (1977) Amer. J. Pathol. 88, 381-386.

196. Capella, C., Bordi, C., Monga, G., Buffa, R., Fontana, P., Bonfanti, S., Bussolati, G. \& Solcia, E. (1978) Virchows Arch., A (Pathol. Anat.) 377, 111-128.
197. Berelowitz, M., Cibelius, M., Epstein, S. \& Bell, N. H. (1980) VI Internat. Congress Endocrinology Melbourne Abstr. No. 76.

198. Sundler, F., Carraway, R. E., Hakanson, R., Aumets, J. \& Dubois, M. P. (1978) Cell Tissue Res. 194, 367-376.

199. Kumasaka, T., Nishi, N., Yaoi, Y., Kido, Y., Saito, M., Okayasu, I., Shimizu, K., Hatakeyama, S., Sawano, S. \& Kokubu, K. (1979) Amer. Obstet. Gynecol. 134, 39-44.

200. Pimstone, B. L., Krohnheim, S. \& Berelowitz, M. (1977) Diabetes 26, S $1,359$.

201. Krohnheim, S., Berelowitz, M. \& Pimstone, B. L. (1978) Diabetes 27, 523-529.

202. Brazeau, P., Epelbaum, G., Tannenbaum, G. S., Rorstad, O. \& Martin, J. (1978) Metabolism 27 S1, 1133-1137.

203. Mackes, K., Itoh, M., Greene, K. \& Gerich, J. (1981) Diabetes 30, 728-734.

204. Patel, Y. C., Rao, K. \& Reichlin, S. (1977) N. Engl. J. Med. 296, 529-533.

205. Kronheim, S., Berelowitz, M. \& Pimstone, B. L. (1977) Clin. Endocrinol. (Oxf.) 7, 343-347.

206. Fitz-Patrick, D. \& Patel, Y. C. (1979) J. Clin. Invest. 64, 737-742.

207. Larsson, L. I., Hirsch, M. A., Holst, J. J., Ingemansson, S., Kühl, C., Jensen, S. L., Lundqvist, G., Rehfeld, J. F. \& Schwartz, T. W. (1977) Lancet $I, 666-668$.

208. Guillemin, R. (1976) Endocrinology 99, 1653-1654.

Dr. Norbert Bethge Institut für Pathologie Universitätsklinikum Steglitz Freie Universität Berlin Hindenburgdamm 30 D-1000 Berlin 45 
